\title{
GEOTHERMOBAROMETRY OF GRANULITES OF THE JUIZ DE FORA COMPLEX AND THE ANDRELÂNDIA GROUP IN THE REGION OF ABRE CAMPO AND MANHUAÇU, MINAS GERAIS, BRAZIL
}

\author{
GEOTERMOBAROMETRIA DE GRANULITOS DO COMPLEXO JUIZ DE FOR A E DO \\ GRUPO ANDRELÂNDIA NA REGIÃO DE ABRE CAMPO E MANHUAÇU, MINAS \\ GERAIS, BRASIL.
}

\section{Edgar Batista de MEDEIROS JÚNIOR ${ }^{1}$, Hanna JORDT-EVANGELISTA ${ }^{1}$, Rodson de Abreu MARQUES ${ }^{2}$, Tamires Costa VELASCO ${ }^{2}$, Caroline Cibele Vieira SOARES $^{2}$}

\author{
E-mail: edgarjr@ymail.com; hanna@degeo.ufop.br \\ carolinecvsoares@gmail.com \\ Introduction \\ Materials and Methods \\ Petrography of Juiz de Fora Complex \\ Petrography of Andrelândia Group \\ Geothermobarometry \\ Discussion \\ Conclusion \\ Acknowledgments \\ References
}

(1) DEGEO/Escola de Minas/UFOP. Campus Morro do Cruzeiro. Ouro Preto, MG.

(2) DEGEL/Alegre Campus/UFES. Alegre, ES. E-mail: rodson.marques@ufes.br; tamires.velasco@ufes.br;

\begin{abstract}
RESUMO - Granulitos máficos e félsicos ortoderivados do Complexo Juiz de Fora e granulitos aluminosos paraderivados do Grupo Andrelândia ocorrem na região de Abre Campo e Manhuaçu, estado de Minas Gerais. As rochas orto- e paraderivadas estão tectonicamente intercaladas como resultado da edificação do Orógeno Araçuaí de idade neoproterozoica. Os granulitos máficos são formados pela associação mineral plagioclásio + ortopiroxênio + clinopiroxênio \pm hornblenda. Os granulitos félsicos são compostos por plagioclásio + quartzo \pm feldspato potássico \pm ortopiroxênio \pm granada. A associação mineral dos granulitos aluminosos é dada por plagioclásio + quartzo + granada + biotita \pm feldspato potássico \pm sillimanita. Os cálculos utilizando a geotermobarometria convencional e o programa THERMOCALC resultaram em temperaturas entre $748{ }^{\circ} \mathrm{C}$ e $870{ }^{\circ} \mathrm{C}$ e pressões entre $5,7 \mathrm{kbar}$ e $7,5 \mathrm{kbar}$ para o metamorfismo de fácies granulito que gerou essas rochas durante o desenvolvimento do Orógeno Araçuaí. A ocorrência local de foliação milonítica e de porfiroclastos intensamente deformados é associada a reativação das zonas cisalhamento Manhuaçu e Abre Campo durante o escape lateral da porção sul do orógeno. Esse estágio é caracterizado pelo desenvolvimento de grandes zonas de cisalhamento transcorrentes dextrais. A exumação dos granulitos do Complexo Juiz de Fora e do Grupo Andrelândia está relacionada ao colapso gravitacional do Orógeno Araçuaí.
\end{abstract}

Palavras-chaves: Complexo Juiz de Fora, Grupo Andrelândia, química mineral, geotermobarometria.

\begin{abstract}
Mafic and felsic ortho-derived granulites of the Juiz de Fora Complex and para-derived aluminous granulites of the Andrelândia Group occur in the Abre Campo and Manhuaçu regions, state of Minas Gerais. The ortho- and para-derived rocks are tectonic intercalated as result of the edification of the neoproterozoic Araçuaí Orogen. The mafic granulites are formed by the mineral assemblage of plagioclase + orthopyroxene + clinopyroxene \pm hornblende. The felsic granulites are composed of plagioclase + quartz + potassium feldspar \pm orthopyroxene \pm garnet. The mineral assemblage of the aluminous granulites is plagioclase + quartz + garnet + biotite \pm potassium feldspar \pm sillimanite. Calculations using conventional geothermobarometry and the THERMOCALC software resulted in temperatures between $748{ }^{\circ} \mathrm{C}$ and $870{ }^{\circ} \mathrm{C}$ and pressures between $5.7 \mathrm{kbar}$ and $7.5 \mathrm{kbar}$ for the granulite facies metamorphism related to the development of the Araçuaí Orogen. The local presence of a mylonitic foliation as well as of intensily deformed porphyroclasts is associated to the reactivation of shear zones as those of Manhuaçu and Abre Campo during southward escape of orogen. This stage is characterized for development of large dextral shear zones. The exhumation of granulites of Juiz de Fora Complex and Andrelandia Group are related to the gravitational collapse of the Araçuaí Orogen.
\end{abstract}

Keywords: Juiz de Fora Complex, Andrelândia Group, mineral chemistry, geothermobarometry.

\section{INTRODUCTION}

The ortho-derived granulites of the Juiz de Fora Complex and the aluminous granulites of the Andrelândia Group in the region of Abre Campo and Manhuaçu, state of Minas Gerais (Fig. 1), are located west of the suture zone of the crystalline core of the neoproterozoic Araçuaí Orogen. The main subject of this research is to understand the metamorphic evolution of these granulites and its role in this portion of the Araçuaí Orogen, and for this several geothermobarometric methods are used.

The Juiz de Fora Complex is composed of five lithologic units (Brandalise, 1991). Unit A consists of enderbite, charnockite, orthoamphibolite, and biotite-amphibole gneiss. Unit $\mathrm{B}$ is composed of garnet-biotite gneiss with or 
without graphite and sillimanite. Unit C consists of mylonite to blastomylonite of biotite gneisses. Unit D is formed by banded and laminated biotite-amphibole gneisses. Finally, unit $\mathrm{E}$ is composed of tonalite-trondhjemite orthogneisses.

Heilbron et al. (1995, 2003, 2004) defined the Juiz de Fora Complex as a variably migmatized granulite facies unit composed of ortho-derived rocks of granite to gabbro compositions. Metasedimentary sequences occur tectonically intercalated within the orthoderived granulites. In Rio de Janeiro state, Heilbron et al. (1995) correlated this metasedimentary cover with the Andrelândia Group. Noce et al. (2007a) extended this correlation to characterize paragneiss, including biotite-garnet and sillimanite-garnet gneisses intercalated with orthoderived granulites of the Juiz de Fora Complex in the studied region.

Available geochronological data for the Juiz de Fora Complex provide paleoproterozoic ages for the crystallization of the protolith of the orthoderived granulites. U-Pb dates determined using laser ablation inductively coupled plasma mass spectrometry (LA-ICP-MS) were reported by Heilbron et al. (2001) to be $2140-2070 \mathrm{Ma}$ and interpreted as the ages for the protolith of the felsic granulites and 2400-1700 Ma as the ages for those of the mafic granulites. The geochronological studies of Heilbron et al. (2010) used isotope dilution thermal ionization mass spectrometry (IDTIMS) and LA-ICP-MS to determine U-Pb dates of $2200-1970 \mathrm{Ma}$ interpreted as the ages for the crystallization of the protoliths of enderbites, charnockites, and mafic granulites and 604-570 $\mathrm{Ma}$ as the ages for the development of the mylonitic foliation under granulite facies metamorphic conditions. Noce et al. (2007b) used the sensitive highresolution ion microprobe to determine $\mathrm{U}-\mathrm{Pb}$ crystallization ages of 2119-2084 Ma for the protoliths of these rocks and 590-574 Ma for the metamorphism. Fischel et al. (1998) reported $\mathrm{Sm}-\mathrm{Nd}$ depleted mantle model ages of 2220-2130 Ma for the Juiz de Fora Complex rocks in the Abre Campo and Manhuaçu regions, indicating the paleoproterozoic juvenile origin. Noce et al. (2007b) interpreted that the Juiz de Fora Complex originated from an island arc setting generated by intra-oceanic subduction during the Paleoproterozoic Era.

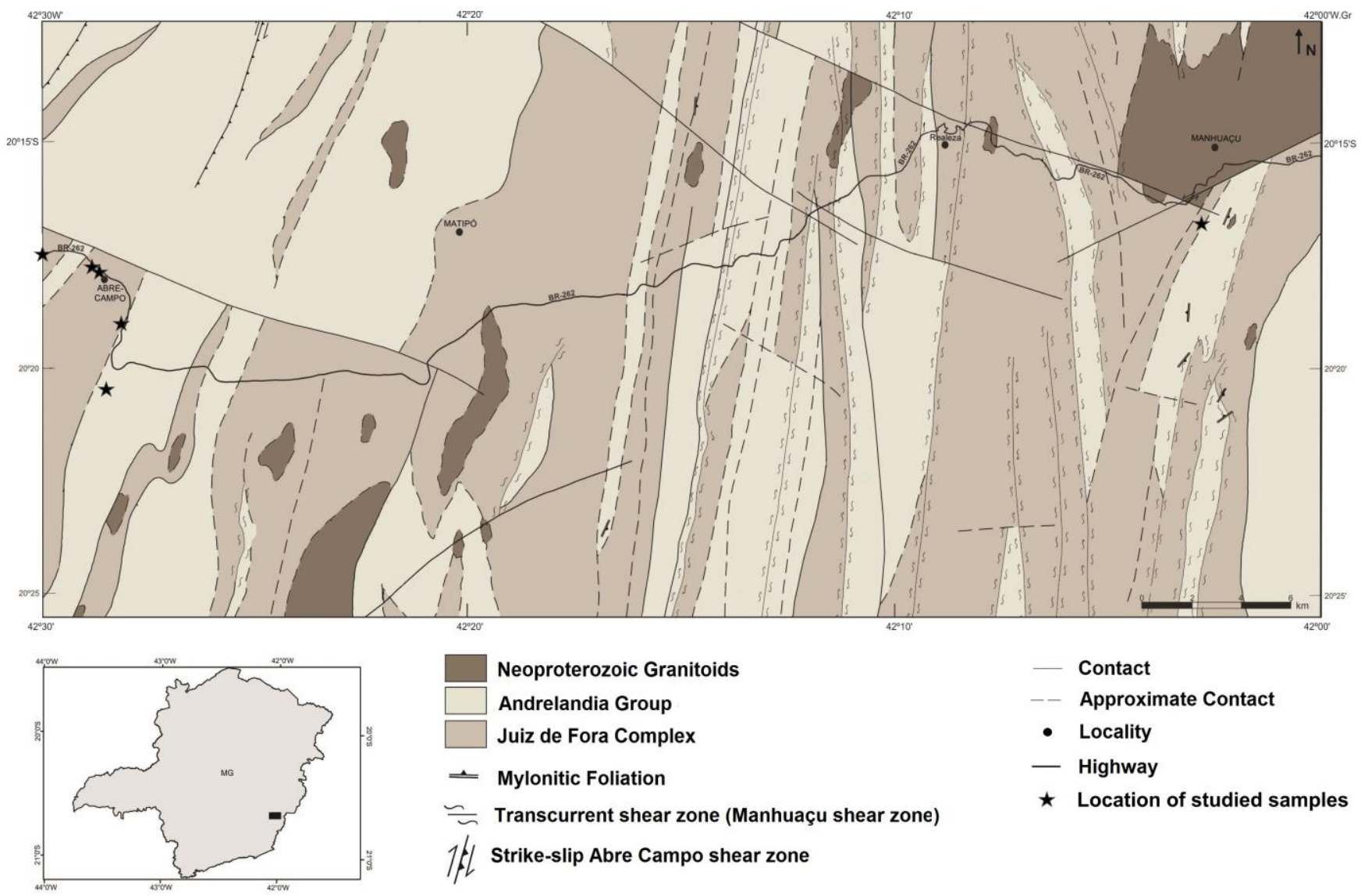

Figure 1 Geological map of the studied region (Noce et al., 2007a). 


\section{MATERIALS AND METHODS}

This study of the metamorphic conditions of the Juiz de Fora Complex and Andrelândia Group in the Abre Campo and Manhuaçu regions is based on petrographic and microstructural characterization, mineral chemistry, and geothermobarometry of the representative lithotypes of these units. Mineral analyses were performed using an electron microprobe (JEOL JXA-8900RL) at $15 \mathrm{kV}$ and a beam current of $20 \mathrm{nA}$ at the Laboratório de Microanálises at Universidade Federal de Minas Gerais. The geothermobarometric calculations for mafic and aluminous granulites were performed on the basis of the mineral chemistry data presented in Tables 1 and 2. Pressure and temperature estimates were based on the orthopyroxene-clinopyroxene, hornblende-pla- gioclase, and garnet-orthopyroxene geothermometers, on the garnet- $\mathrm{Al}_{2} \mathrm{SiO}_{5}$-quartzplagioclase (GASP) geobarometer and on THERMOCALC software version 3.33 (Powell and Holland, 1994), with thermodynamic date set assembled on November 2003. Additionally, the program RCLC of Pattison et al. (2003) was utilized for calculate pressuretemperature conditions of Grt-Opx-Pl-Qtz assemblage in felsic granulites. The method is based on Al-solubility in orthopyroxene in equilibrium with garnet, corrected for late $\mathrm{Fe}$ $\mathrm{Mg}$ exchange. The calculations of Aloctahedral in orthopyroxene presented in this study are based in the model $2\left[\mathrm{X}_{\mathrm{Al}}^{\mathrm{Opx}}=\mathrm{Al} / 2\right]$, recommended for granulites by Pattison et al. (2003).

\section{PETROGRAPHY OF THE JUIZ DE FORA COMPLEX}

The Juiz de Fora Complex is commonly composed of banded mafic and felsic granulites. This irregular banding is characterized by alternating layers of felsic granulites and mafic granulites that also present variable degrees of migmatization (Fig. 2a). The migmatites are classified as net-rich to stromatic metatexites with hornblende-rich restites and irregular quartz-feldspathic leucosome.

The felsic granulites have a tonalite to granite composition. The texture is granoblastic, granolepidoblastic to granonematoblastic, but locally a mylonite foliation and feldspar porphyroclasts are observed. They contain 35-60 vol\% of quartz, $20-60 \%$ of plagioclase, $0-35 \%$ of potassium feldspar, 0 $4 \%$ of garnet, $5-20 \%$ of biotite, $0-15 \%$ of hornblende, and $0-20 \%$ of orthopyroxene (Figs. $3 \mathrm{a}$ and $3 \mathrm{~b}$ ). Accessory minerals include zircon, apatite, and opaque minerals; minerals of secondary origin include sericite, carbonate, actinolite, and epidote. Quartz is xenoblastic and its grain size varies between $0.1 \mathrm{~mm}$ and 3 $\mathrm{mm}$. The largest grains frequently exhibit strong undulatory extinction. The grains commonly have interlobated and sutured boundaries and form core-mantle microstructures. In some domains, the grains are elongated with an axial ratio of approximately 5:1. Feldspars are anhedral to subhedral and measure 0.1-9 $\mathrm{mm}$. The potassium feldspar is perthitic and has incipient tartan twinning. The plagioclase is frequently antiperthitic and has flexured polysynthetic twinning. Partial substitution by epidote, sericite, or carbonate is observed as blobs in some grains. The plagioclase composition is andesine (An40An45), cores of the grains being commonly more calcic than the rims. The feldspars exhibit core-mantle microstructures (Fig. 3c) characterized by porphyroclasts that present strong undulatory extinction. The smaller grains of the recrystallized matrix present interlobated to sutured boundaries. The garnet is subidioblastic to xenoblastic and its grain-size varies between $1.5 \mathrm{~mm}$ and $4 \mathrm{~mm}$, with inclusions of biotite, quartz, and plagioclase. The garnet is composed of $64-71 \%$ almandine, 16-22\% pyrope, 3-8\% grossular and $4-5 \%$ spessartine. The biotite is frequently oriented and has a reddish-brown to pale yellow pleochroism; $\mathrm{Ti}$ amount is 0.55 to 0.56 a.p.f.u and $\mathrm{X}_{\mathrm{Mg}}$ varies between 0.54 and 0.56 . Common inclusions are apatite, opaque minerals, and zircon. The orthopyroxene is xenoblastic, presents pink to pale-green pleochroism, and its grain-size varies between $0.1 \mathrm{~mm}$ and $2 \mathrm{~mm}$. Chemically, the orthopyroxene can be classified as hypersthene to Fe-hypersthene (En42-En55). The grains are frequently oriented and exhibit weak undulatory extinction and fractures; partial substitution by biotite and actinolite is observed at rims and cleavages. The hornblende is subidioblastic and has brownish-green and dark 
Table 1 Chemical composition (weight \%) of minerals in mafic granulite (sample AC-12A) and felsic granulite (sample $\mathrm{AC}-12 \mathrm{C})$ and their cationic distribution.

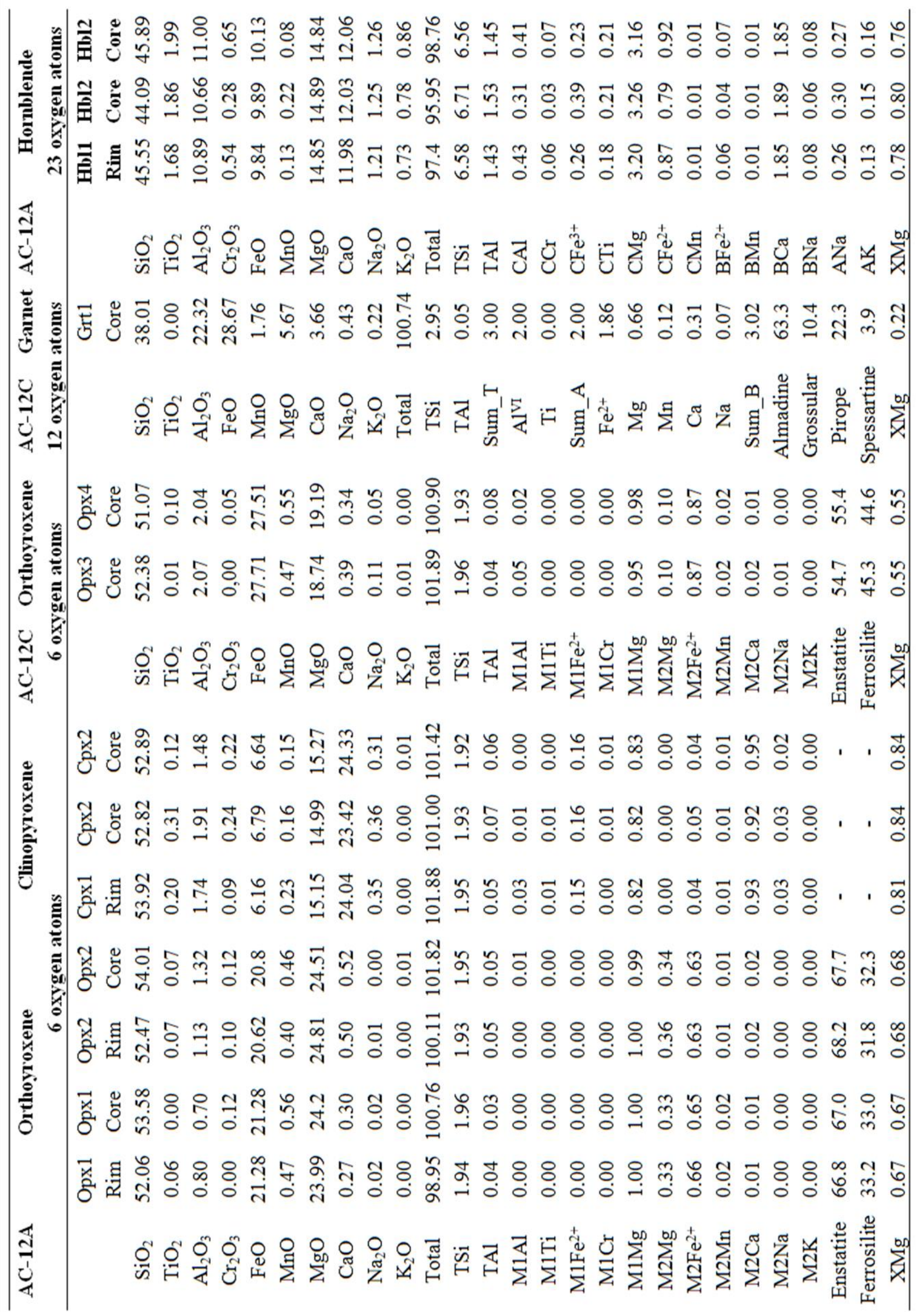


Table 2 Chemical composition (weight \%) of minerals in mafic granulite (sample AC-12A) and aluminous granulite (sample MANH-2) and their cationic distribution

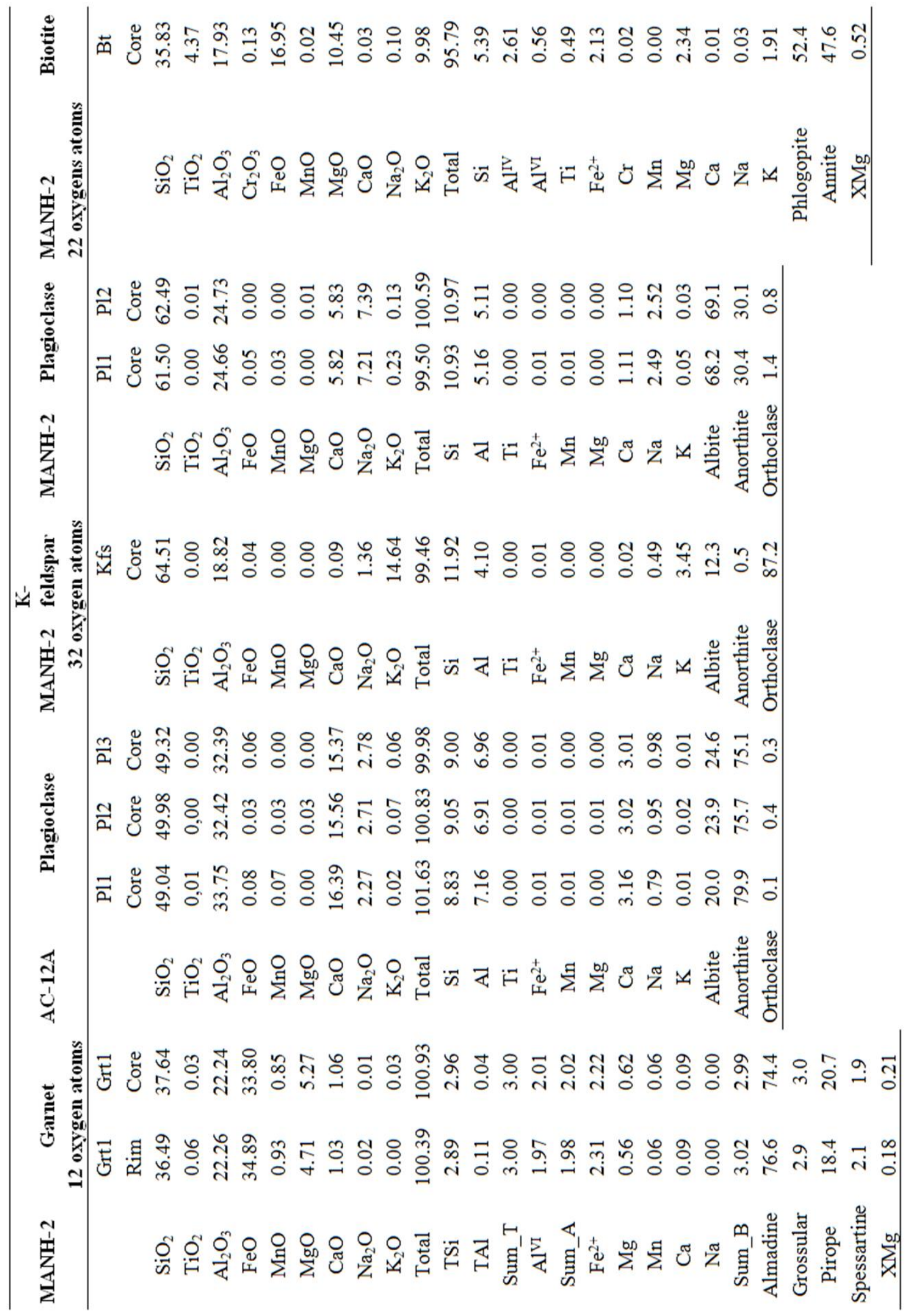


brown to pale green pleochroism. The grains are oriented and are partially substituted by biotite in their rims. The inclusions of apatite and opaque minerals are common in the amphibole.

The mafic granulites have granoblastic texture. However, some are characterized by porphyroclasts of pyroxene involved by a prominent mylonite foliation. These rocks contain 2-20 vol\% of orthopyroxene, $0-20 \%$ of clinopyroxene, $35-50 \%$ of plagioclase, $0-30 \%$ of hornblende, $10 \%$ of quartz, and $0-6 \%$ of biotite (Fig. 3d). Accessory minerals are apatite, opaque minerals, sphene, and zircon; secondary minerals are sericite, carbonate, epidote, and cummingtonite. The plagioclase is xenoblastic and grain-size varies between 0.1 $\mathrm{mm}$ and $5 \mathrm{~mm}$. The grains exhibit flexured polysynthetic twinning and core-mantle microstructures with interlobated to sutured boundaries. There is a partial substitution by sericite, carbonate, or epidote. Chemically, this plagioclase is more calcic than that of the felsic granulites, being classified as bytownite (An72-An80). A higher concentration of calcium is observed in the cores of the grains.
Both pyroxenes are xenoblastic and grain-size varies between $0.1 \mathrm{~mm}$ and $2 \mathrm{~mm}$. Some grains are fractured and partially substituted by amphiboles such as cummingtonite and hornblende in addition to biotite. In this case, biotite occurs in the cleavages and microfractures. The partial substitution by cummingtonite and hornblende is observed at rims and the first only occurs as substitution of orthopyroxene. The concentration of the enstatite component in the orthopyroxene is En67-En68, higher than in the felsic granulites. The clinopyroxene is classified as diopside. The hornblende is xenoblastic to subidioblastic and has grain-size between $0.1 \mathrm{~mm}$ and $1.5 \mathrm{~mm}$. Some grains present dark green and pale brown to greenish-brown pleochroism and have inclusions of apatite. Other grains exhibit green and pale brown pleochroism and replaced pyroxene. Biotite is subidioblastic and has inclusions of apatite and zircon; some grains exhibit preferred orientation, parallel to main foliation. Quartz occurs as xenoblastic grains with 0.1-3 mm. The grains exhibit deformation evidence such as sutured boundaries, strong undulatory extinction, and subgrains.

\section{PETROGRAPHY OF THE ANDRELÂNDIA GROUP}

The Andrelândia Group is composed of aluminous granulites intercalated with mafic and felsic granulites of the Juiz de Fora Complex. The commonly migmatitic aluminous granulites can be classified as stromatic metatexite and diatexite. The neosome is characterized by high concentration of garnet (Fig. 2 b) and the euhedral feldspar crystals, typical of magmatic crystallization, are evidence that the rocks underwent partial melting. Some lithotypes have a mylonite foliation (Fig. 2c) trending north-south and with a sub-vertical dip. The aluminous granulites are granolepidoblastic to granonematoblastic. The foliation is characterized by the preferential orientation of biotite and sillimanite. The mineralogical composition includes 20-35 vol\% of quartz, $20-40 \%$ of plagioclase, $0-25 \%$ of potassium feldspar, 10-20\% of garnet, 3$16 \%$ of biotite, and $0-6 \%$ of sillimanite. Accessory minerals are zircon, apatite, and opaque minerals; minerals of secondary origin are sericite, carbonates, and epidote. Quartz occurs as xenoblastic grains with 0.1 and $3 \mathrm{~mm}$, some grains exhibit undulatory extinction and core-mantle microstructures with interlobated and sutured boundaries. The plagioclase is xenoblastic to idioblastic and grain-size varies between 0.5 to $7 \mathrm{~mm}$. The grains often show flexured polysynthetic twinning, antiperthitic exsolution, and interlobated to sutured boundaries. Some grains were partially substituted by sericite and epidote. Chemically, the plagioclase can be classified as andesine to labradorite (An30-An56) similar to that of the felsic granulites. The potassium feldspar is xenoblastic and grain-size varies between 0.1 $\mathrm{mm}$ and $8 \mathrm{~mm}$. The grains frequently show myrmekite at rims and exhibit incipient Tartan twinning. Garnet occurs as xenoblastic to subidioblastic porphyroblasts with 0.5 to 10 $\mathrm{mm}$. They are poikiloblastic (Fig. 3e) with inclusions of quartz, plagioclase, and biotite; some inclusions of plagioclase are vermiform. Garnet is composed of 57-77\% almandine, 16$37 \%$ pyrope, 3-6\% grossular and $1 \%-2 \%$ spessartine. In comparison the garnet of felsic granulites is less magnesian. Biotite is idioblastic and has reddish-brown to pale yellow pleochroism. The $\mathrm{Ti}$ amount is 0.57 to 0.60 a.p.f.u and $\mathrm{X}_{\mathrm{Mg}}$ varies between 0.63 and 0.72 and are similar to that of the biotite in 
felsic granulites, although it is more aluminous $\left(\mathrm{Al}^{\mathrm{IV}}\right)$ than the one in the felsic granulites. The biotite often is intergrown with sillimanite and oriented in the direction of foliation (Fig. 3f). Sillimanite is subidioblastic and frequently occurs as fibrolite. Some needles may occur rimming the garnet porphyroblasts.

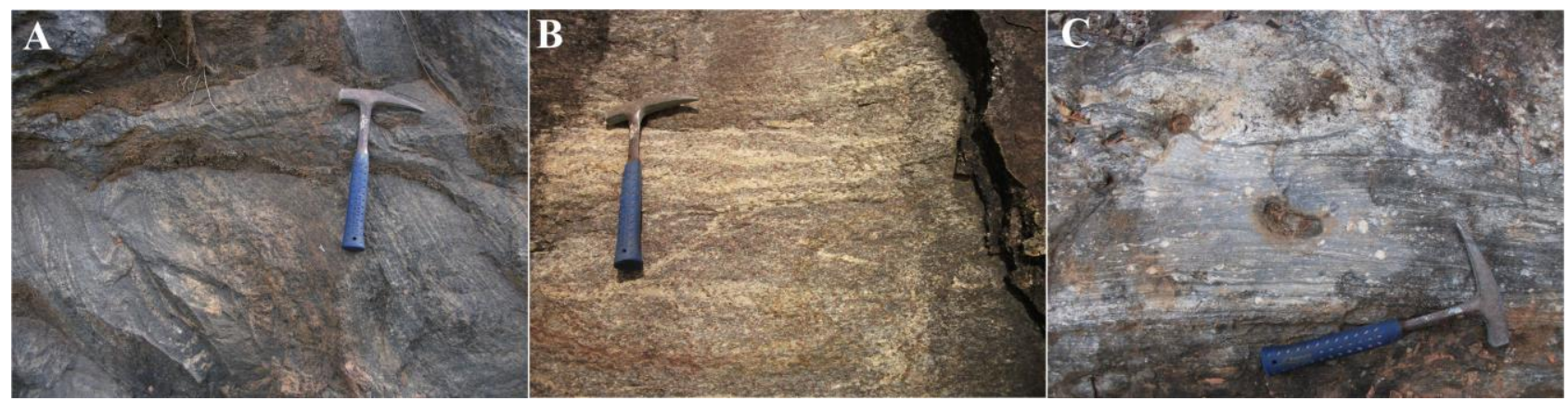

Figure 2 Outcrops of mafic and aluminous granulites. A: Irregular banding of mafic granulite of the Juiz de Fora Complex. B: High concentration of garnet in the neosome of the aluminous granulite of the Andrelândia Group. C: Strongly mylonitized aluminous granulite.
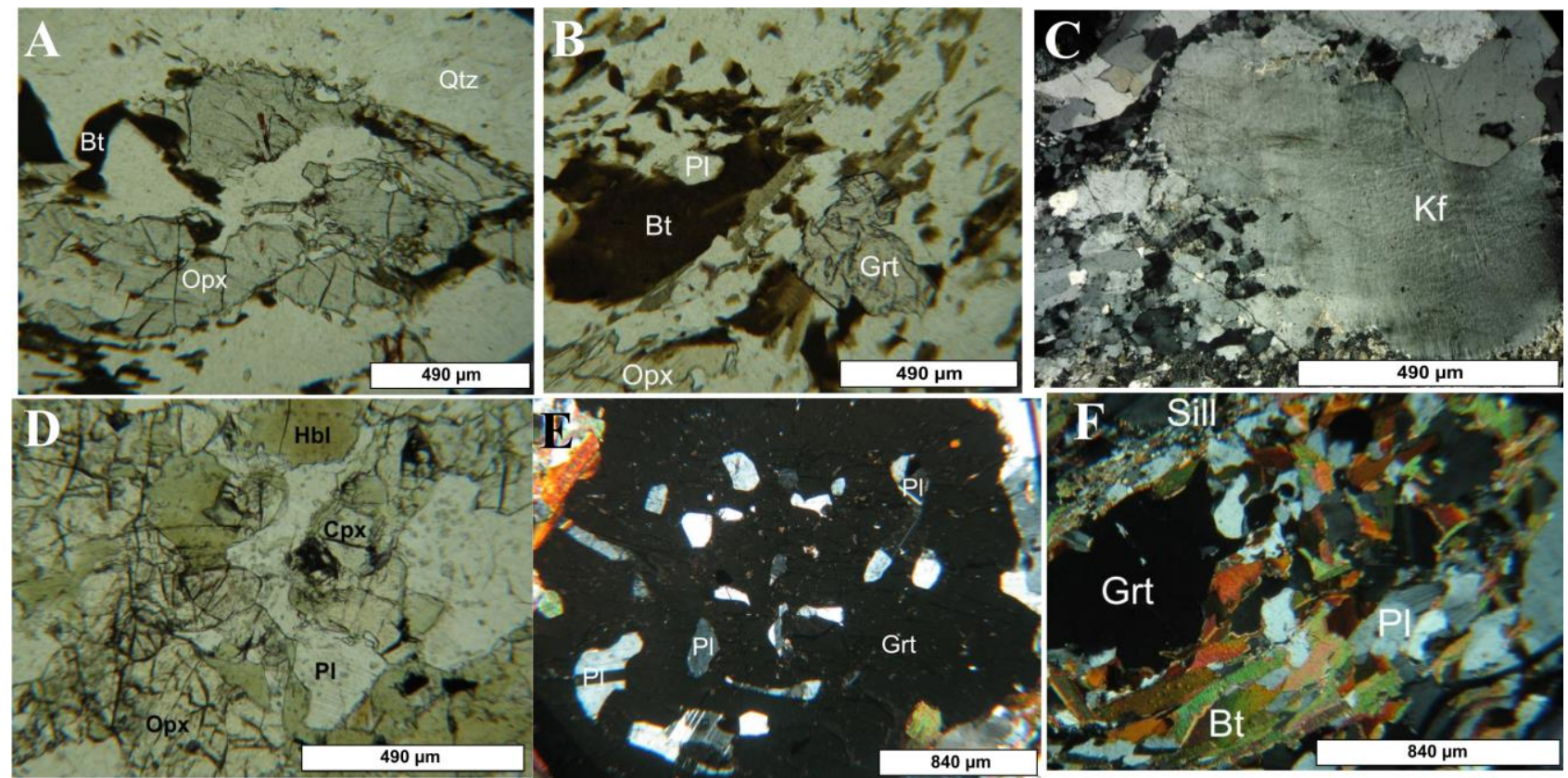

Figure 3 Photomicrographs of lithotypes of the Juiz de Fora Complex and the Andrelândia Group. A and B: Felsic granulite composed of plagioclase (Pl), quartz (Qtz), garnet (Grt) and orthopyroxene (Opx) with biotite (Bt) (PPL). C: Potassium feldspar exhibit core-mantle microstructure in felsic granulite (XPL). D: Mafic granulite with orthopyroxene (Opx), clinopyroxene (Cpx), plagioclase (Pl), and hornblende (Hbl) (PPL). E: Poikiloblastic garnet (Grt) in aluminous granulite with inclusions of plagioclase (XPL). F: Garnet (Grt) in aluminous granulite with plagioclase (Pl), biotite (Bt) and sillimanite (Sill) (XPL). PPL: plane-polarized light; XPL: crossed-polarized light.

\section{GEOTHERMOBAROMETRY}

The felsic granulites of the Juiz de Fora Complex are characterized by the following mineral assemblage: plagioclase + quartz \pm potassium feldspar \pm orthopyroxene \pm garnet. The occurrence of orthopyroxene indicates metamorphic conditions of the granulite facies. The temperatures were estimated by the garnetorthopyroxene exchange Fe-Mg geothermometer calibrated by Wood and Banno (1973) and by Harley (1984). The first calibration resulted in temperatures between $688{ }^{\circ} \mathrm{C}$ and $905{ }^{\circ} \mathrm{C}$, assuming a pressure of $7 \mathrm{kbar}$. The temperatures obtained with calibration made by Harley (1984) are lower, between $688{ }^{\circ} \mathrm{C}$ and $650{ }^{\circ} \mathrm{C}$. Calculations using THERMOCALC resulted in temperatures of $859 \pm 147{ }^{\circ} \mathrm{C}$ and pressures of $7.5 \pm 1.8$ kbar. The large temperature uncertainty also suggests chemical disequilibrium as a result of the retrometamorphic process. The results of 
program RCLC confirm this hypothesis because the initial intersection of equilibria between garnet-orthopyroxene geothermometer (Fe-Mg exchange) and garnet-orthopyroxeneplagioclase-quartz geobarometer resulted in low-temperature $\left(662{ }^{\circ} \mathrm{C}\right)$ and pressure of 6.5 kbar. The converged values obtained correspond to conditions around $740{ }^{\circ} \mathrm{C}$ and 7.3 kbar. According to the idealizers of the program RCLC, the converged values represent the most reliable results.

The mafic granulites of the Juiz de Fora Complex have the following mineral assemblage: plagioclase + orthopyroxene + clinopyroxene \pm hornblende. The conditions of temperature were calculated by using the orthopyroxene-clinopyroxene calibration of Kretz (1982) and the hornblende-plagioclase calibrated by Holland and Blundy (1994). The first geothermometer, based on the cationic exchange of $\mathrm{Fe}$ and $\mathrm{Mg}$ between orthopyroxene and clinopyroxene, resulted in temperatures between 655 and $722{ }^{\circ} \mathrm{C}$. The HB-PL software of Holland and Blundy (1994) was utilized for calculation in hornblende-plagioclase geothermometer. The estimations of temperature are based on two reactions that represent two independent geothermometers, resulted in temperatures between 762 and $891{ }^{\circ} \mathrm{C}$, considering a pressure of $5 \mathrm{kbar}$. The two aforementioned reactions are:

$$
\begin{aligned}
& \text { edenite }+4 \text { quartz }=\text { tremolite }+ \text { albite } ;(1) \\
& \text { edenite }+ \text { albite }=\text { richterite }+ \text { anorthite } .(2)
\end{aligned}
$$

The results obtained with THERMOCALC are $870 \pm 39{ }^{\circ} \mathrm{C}$ and $7.6 \pm 3.4 \mathrm{kbar}$, assuming a molar fraction of $\mathrm{H}_{2} \mathrm{O}=0.3$. This value for water activity was choosen because it represents the most probable pressure and temperature conditions for the generation of mafic granulites, meaning lowest uncertainties

(sigfit $=0.70)$. The maximum sigfit value for calculations to obtain $95 \%$ reliability is 1.54 . The large uncertainty of pressure suggests disequilibrium among the mineral phases of the assemblage, although the result is concordant with the pressure obtained for the felsic granulites. The temperatures are more consistent in this case.

The aluminous granulites of the Andrelândia Group have the following mineral assemblage: plagioclase + quartz + garnet + biotite \pm potassium feldspar \pm sillimanite. The conditions of pressure were calculated by means of the GASP geobarometer based on Reaction 3:

$$
\text { grossular }+\mathrm{Al}_{2} \mathrm{SiO}_{5}+\text { quartz }=\text { anorthite. (3) }
$$

The results are 5.8-6.0 kbar after the Newton and Haselton (1981) calibration, 4.34.4 kbar after Hodges and Spear (1982), 6.66.7 kbar after Koziol and Newton (1988), and 7.5-7.7 kbar after the Koziol (1989) calibration, assuming a temperature of $800{ }^{\circ} \mathrm{C}$. The calculations based on THERMOCALC resulted in $748 \pm 44{ }^{\circ} \mathrm{C}$ and $5.7 \pm 1.5 \mathrm{kbar}$, considering a molar fraction of $\mathrm{H}_{2} \mathrm{O}=0.3$. This value for water activity represents the pressure and temperature conditions characterized for lowest uncertainties (sigfit $=0.32$ ). The maximum sigfit value for calculations to obtain $95 \%$ reliability is 1.73 .

These conditions characterize granulite facies metamorphic rocks of lower to intermediate pressure. The results obtained for the Juiz de Fora Complex are compatible with these estimates of pressure and temperature, although the mafic granulites were formed in relatively higher temperature conditions. The difference of temperature obtained for these units can be result of metamorphism of granulite facies at relatively distinct crustal levels

\section{DISCUSSION}

The results of geothermobarometry indicate conditions of the granulite facies for the rocks of the Juiz de Fora Complex and the Andrelândia Group. The mafic granulites were formed at temperatures and pressures of about $870{ }^{\circ} \mathrm{C}$ and $7.6 \mathrm{kbar}$. The mineral association of these rocks is orthopyroxene + clinopyroxene + plagioclase \pm hornblende \pm quartz, which is typical of medium-pressure granulites. The continuous reaction (4) reported by Spear (1995) indicates that reactants and products may constitute a stable paragenesis at temperatures of approximately $800{ }^{\circ} \mathrm{C}$ :

$$
\begin{aligned}
& \text { hornblende }+ \text { quartz }=\text { orthopyroxene }+ \\
& \text { clinopyroxene }+ \text { plagioclase }+ \text { liquid (4). }
\end{aligned}
$$

The felsic granulites were formed under similar conditions with temperatures and 
pressures of approximately $800{ }^{\circ} \mathrm{C}$ and 7.5 kbar. The mineral association is plagioclase + quartz \pm potassium feldspar \pm orthopyroxene \pm garnet. The presence of igneous features such as feldspar euhedral indicates the occurrence of partial melting during metamorphism. Reaction (5) shows the formation of orthopyroxene and the generation of liquid from the dehydration of biotite at temperatures of $750-800{ }^{\circ} \mathrm{C}$ and a low molar fraction of $\mathrm{H}_{2} \mathrm{O}$, as described by Graphchikov and Konilov (1996):

$$
\begin{gathered}
\text { biotite }+ \text { quartz }=\text { orthopyroxene }+ \text { potassium } \\
\text { feldspar }+ \text { liquid }(5) .
\end{gathered}
$$

The aluminous granulites of the Andrelândia Group were generated under conditions similar to those of the Juiz de Fora rocks. The geothermobarometry resulted in a temperature of $748{ }^{\circ} \mathrm{C}$ and a pressure of $5.7 \mathrm{kbar}$. The mineral association plagioclase + quartz + garnet + biotite \pm potassium feldspar \pm sillimanite is representative of metamorphic rocks derived from sedimentary protoliths. These rocks also present evidence of partial melting. In this case, reaction (6) describes the generation of liquid and sillimanite from muscovite dehydration. According to Spear (1995), this reaction occurs at approximately $750{ }^{\circ} \mathrm{C}$ and $6-8 \mathrm{kbar}$ in the $\mathrm{K}_{2} \mathrm{O}-\mathrm{FeO}-\mathrm{MgO}-$ $\mathrm{Al}_{2} \mathrm{O}_{3}-\mathrm{SiO}_{2}-\mathrm{H}_{2} \mathrm{O}$ (KFMASH) system with low molar fraction of $\mathrm{H}_{2} \mathrm{O}$. In a more complex system like $\mathrm{CaO}-\mathrm{Na}_{2} \mathrm{O}-\mathrm{K}_{2} \mathrm{O}-\mathrm{FeO}-\mathrm{MgO}-\mathrm{Al}_{2} \mathrm{O}_{3}-$ $\mathrm{SiO}_{2}-\mathrm{H}_{2} \mathrm{O}-\mathrm{TiO}_{2}-\mathrm{O}_{2}$ (CNKFMASHTO) another reaction can be crossed in these conditions. Reaction (5) for the felsic granulites and reactions (6) and (7) for the aluminous granulites represents the formation of peritectic phases such as the potassium feldspar. The euhedral texture identified in some of the studied rocks is characteristic of growth in the presence of a liquid.

$$
\begin{gathered}
\text { muscovite }+ \text { quartz }=\text { sillimanite }+ \text { potassium } \\
\text { feldspar }+ \text { liquid }(6) .
\end{gathered}
$$

biotite + sillimanite + quartz + plagioclase $1=$ potassium feldspar + plagioclase $2+$ garnet + ilmenite + liquid (7)

Noce et al. (2007b) and Heilbron et al. (2010) interpreted the Juiz de Fora Complex as the basement of the Andrelandia Group. The Juiz de Fora Complex is a polymetamorphic unit characterized by a metamorphic evolution related to the Paleoproterozoic and to the Neoproterozoic (Noce et al., 2007b). Heilbron et al. (2010) reported that the protoliths of the Andrelândia Group were deposited in a neoproterozoic sedimentary basin of a passive margin. The granulite facies metamorphism that affected the Juiz de Fora Complex and the Andrelândia Group is related to development of Araçuaí Orogen during the Neoproterozoic (Belém et al., 2011). During this process, partial melting occurred in the felsic and the aluminous granulites. The mylonite microstructures were probably generated under the influence of the Manhuaçu and the Abre Campo shear zones. The intimate relationship of mafic and felsic granulites with Andrelândia rocks are associated with reactivation of these shear zones during evolution of the Araçuaí Orogen in the Brasiliano tectono-metamorphic event.

\section{CONCLUSIONS}

The Andrelândia Group represents the neoproterozoic cover of the Juiz de Fora Complex (Heilbron et al. 2010). The rocks of these two units were metamorphosed under granulite facies conditions with temperatures of $748-870{ }^{\circ} \mathrm{C}$ and pressures of 5.7-7.5 kbar during the collisional stage of development of the Araçuaí-West Congo Orogen (Alkmim et al. 2006). The temperature of this process is associated with a low molar fraction of $\mathrm{H}_{2} \mathrm{O}$, which enabled partial melting in the felsic granulites of the Juiz de Fora Complex and of the aluminous granulites of the Andrelândia Group. The temperature conditions obtained for
Juiz de Fora Complex are higher because this unit was metamorphosed into a relatively deeper crustal level. In the region between Abre Campo and Manhuaçu, mafic and felsic granulites of the Juiz de Fora Complex are intimately intercalated with the aluminous granulites of the Andrelândia Group that is the result of a tectonic association of the two units (Noce et al., 2007b). The intercalation of these units was provided by reactivation of Abre Campo and Manhuaçu shear zones during the late collisional stage of Araçuai-West Congo Orogen. This stage is denominated by Alkmim et al. (2006) like southward escape of orogen 
because it is characterized for development of large dextral shear zones. The exhumation of granulites probably is related to the gravitational collapse of the Araçuai-West Congo Orogen at about $500 \mathrm{Ma}$ ago as reported by Alkmim et al. (2006).

\section{ACKNOWLEDGMENTS}

The authors are grateful to FAPEMIG for financial support for the Project APQ-00732-12. We thank reviewer for constructive review and comments.

\section{REFERENCIAS}

ALKMIM, F.F., MARSHAK, S., PEDROSA-SOARES, A.C., PERES, G.G., CRUZ, S. \& WHITTINGTON, A. Kinematic evolution of the Araçuaí-West Congo Orogen in Brazil and Africa: nutcracker tectonics during the neoproterozoic assembly of Gondwana. Precambrian Research, v. 149, p. 43-64, 2006.

BELÉM, J., PEDROSA-SOARES, A.C., NOCE, C.M., SILVA, L.C., ARMSTRONG, R., FLECK., A., GRADIM, C. \& QUEIROGA, G. Bacia precursora versus bacias orogênicas: exemplos do Grupo Andrelândia com base em datações U-Pb (LA-ICP-MS) em zircão e análises litoquímicas. Geonomos, v. 19, n. 2, p. 224-243, 2011.

BRANDALISE, L.A. Programa levantamentos geológicos básicos do Brasil. Folha Ponte Nova, SF.23-X-B-II. Escala 1:100.000. Brasília, DNPM/CPRM, 1991, 194p.

BREY, G. T., KÖHLER, T. Geothermobarometry in four phase lherzolites, part II: new thermobarometers, and practical assessment of existing thermobarometers. Journal of Petrology, v. 31, p. 1353-1378, 1990.

FISCHEL, D.P., PIMENTEL, M.M., FUCK, R.A., COSTA, A.G. \& ROSIÈRE, C.A. Geology and Sm-Nd isotopic data for the Mantiqueira and Juiz de Fora complexes (Ribeira Belt) in the Abre Campo Manhaçu region, Minas Gerais, Brazil. In: International Conference on Basement Tectonics, 14, Abstracts, p. 21-23, 1998.

GRAPHCHIKOV, A.A. \& KONILOV, A.N. Experimental study of partial melting of biotite-orthopyroxene-quartz bearing assemblages in the system $\mathrm{KAlO}_{2}-\mathrm{MgO}-\mathrm{FeO}-\mathrm{SiO}_{2}-\mathrm{H}_{2} \mathrm{O}$. European Journal of Mineralogy, v. 8, p. 143-152, 1996.

HARLEY, S.L. An experimental study of the partitioning of Fe and $\mathrm{Mg}$ between garnet and orthopyroxene. Contrib. Mineral. Petrol., v. 86, p. 359-373, 1984.

HEILBRON, M., VALERIANO, C.M., VALLADARES, C.S. \& MACHADO, N. A orogênese brasiliana no segmento central da Faixa Ribeira, Brasil. Revista Brasileira de Geociências, v. 25, n. 4, p. 249-266, 1995.

HEILBRON, M., MACHADO, N. \& DUARTE, B.P. Revealing the paleoproterozoic transamazonian Orogen hiding in the neoproterozoic Ribeira Belt, SE Brazil. In: Geological Association of Canada/Mineralogical Association of Canada Joint Annual Meeting, St. Johns, Canada, Abstracts, v. 26, p. 61, 2001.

HEILBRON, M., DUARTE, B., VALLADARES, C., NOGUEIRA, J.R., TUPINAMBÁ, M. \& EIRADO, L.G. Síntese geológica do Bloco Oriental (Zona da Mata). In: A. C. PEDROSA SOARES, C. M. NOCE, R. TROUW \& M. HEILBRON (orgs.), Projeto Sul de Minas - Etapa I: Geologia e Recursos Minerais do sudeste mineiro. Belo Horizonte, COMIG/UFMG/UFRJ/UERJ, p. 8-50, 2003.

HEILBRON M., PEDROSA-SOARES A.C., CAMPOS-NETO M., SILVA L.C., TROUW R.A.J. \& JANASI V.C. A Província Mantiqueira. In: V. MANTESSO-NETO, A. BARTORELLI, C. D. R. CARNEIRO \& B. B. NEVES (EDS.), Geologia do Continente Sul-Americano: Evolução da obra de Fernando Flávio Marques de Almeida. São Paulo, BECA, p. 203-234, 2004.

HEILBRON, M., DUARTE, B.P., VALERIANO, C.M., SIMONETTI, A., MACHADO, N. \& NOGUEIRA, J.R. Evolution of reworked paleoproterozoic basement rocks within the Ribeira Belt (neoproterozoic), SE-Brazil, based on
$\mathrm{U}-\mathrm{Pb}$ geochronology: implications for paleogeographic reconstructions of the São Francisco-Congo Paleocontinent. Precambrian Research, v. 178, p. 136-148, 2010.

HODGES, K. V. \& SPEAR, F. S. Geothermometry, geobarometry and the $\mathrm{Al}_{2} \mathrm{SiO}_{5}$ triple point at Mt. Moosilauke, New Hampshire. Am. Mineral., v. 67, p. 1118-1134, 1982.

HOLLAND, T. \& BLUNDY, J. Non-Ideal interaction in calcic amphiboles and their bearing on amphibole-plagioclase thermometry. Contributions to Mineralogy and Petrology, v. 116, n. 4 , p. $433-447,1994$.

KOZIOL, A.M. Recalibration of the garnet-plagioclase$\mathrm{Al}_{2} \mathrm{SiO}_{5}$-quartz (GASP) geobarometer and applications to natural paragenesis. $\boldsymbol{E O S}$, v. 70, n. 15, p. 493, 1989.

16. KOZIOL, A.M. \& NEWTON, R.C. Redetermination of the anorthite breakdown reaction and improvement of the plagioclase-garnet-Al2SiO5-quartz geobarometer. American Mineralogist, v. 73, p. 216-223, 1988.

KRETZ, R. Transfer and exchange equilibria in a portion of the pyroxene quadrilateral as deduced from natural and experimental data. Geochimica Cosmochimica Acta, v. 46, p. 411-422, 1982

NEWTON, R.C. \& HASELTON, H.T. Thermodynamics of the garnet-plagioclase- $\mathrm{Al}_{2} \mathrm{SiO}_{5}$-quartz geobarometer. In: NEWTON, R.C., NAVROTSKY, A., WOOD, B.J. ed. Thermodynamics of Minerals and Melts. 1 ed. New York: Springer-Verlag, 1981, 293 p., cap. 7, p. 131-147.

NICKEL, K. G. \& GREEN, D. H. Empirical geothermobarometry for garnet peridotites and implications for the nature of the lithosphere, kimberlites and diamonds. Earth \& Planet. Sci. Lett., v. 73, p. 158-170, 1985.

NOCE, C.M., COSTA, A.G., PIUZANA, D., VIEIRA, V.S. \& CARVALHO C.M. Programa levantamentos geológicos básicos do Brasil. Folha Manhuaçu, SF.23-X-B-III. Escala 1:100.000. Belo Horizonte, UFMG/CPRM, 2007a, 44p.

NOCE, C.M, PEDROSA-SOARES, A.C., SILVA, L.C., ARMSTRONG, R. \& PIUZANA, D. Evolution of polycyclic basement complexes in the Araçuaí Orogen, based on U-Pb shrimp data: implications for Brazil-Africa links in paleoproterozoic time. Precambrian Research, v. 159, p. 60$78,2007 \mathrm{~b}$

PATTISON, D.R.M., CHACKO, T., FARQUHAR, J., MCFARLANE, C.R.M. Temperatures of granulite-facies metamorphism: constraints from experimental phase equilibria and thermobarometry corrected for retrograde exchange. Journal of Petrology, v. 44, n. 5, p. 867-900, 2003.

POWELL, R. \& HOLLAND, T. Optimal geothermometry and geobarometry. American Mineralogist, v. 79, p. 120-133, 1994.

SPEAR, F.S. Metamorphic Phase Equilibria and PressureTemperature-Time Paths. Washington: Mineralogical Society of America Monograph, 1995. 799p.

WOOD, B.J. \& BANNO, S. Garnet-Orthopyroxene and Orthopyroxene-Clinopyroxene Relationships in Simple and Complex Systems. Contributions to Mineralogy and Petrology, v. 42, p. 109-124, 1973.

Submetido em 16 de novembro de 2015 Aceito em 11 de maio de 2017 